\title{
KITAP TANITMA
}

\author{
Dr. Yavuz SABUNCU
}

\section{KAMU HUKUKUNDA YENI GELIŞMELER}

\section{"NEUE ENTWICKLUNGEN IM ÖFFENTLICHEN RECHT"}

Beiträge 'zum Verhältnis von Bürger und Staat aus Völkerrecht, Verfassungsrecht und Verwaltungsrecht

Herausgegeben von Thomas Berberich, Wolfgang Holl und Kurt Jürgen Maas.

Verlag W. Kohlhammer GmbH, Stutgart 1979.

Yapit, Alexander von Humbolt vakfınin, Ludwigsburg'da 10 - 14 Ekim 1978 tarihleri arasında düzenlediği uluslararası sempozyumda sunulan bildirilerden oluşuyor. Türkiye'den de üç bilim adaminın ARMAĞAN, TİKVEŞ, SAĞLAM) katıldığı toplantının tartışmalanna yapitta yer verilmemiş.

Kitap üç bölüm. İlk bölüm Devletler Hukuku, İkinci Bölüm Anayasa Hukuku, son bölüm ise İdare Hukuku alanlarında verilen bildirileri kapsiyor. Ben burada Anayasa Hukuku ile ilgili bölümü tanitmaya çalışacağım.

Anayasa Hukuku ile ilgili bildirilerin bazlları serbestçe yapılmıs konuşmalar niteliğinde. GEIGER'in "Alman Bakş Açısı ile Anayasa Yargisının Güncel Sorunlan" adlı bildirisi ile, HALLER'in "Avusturya'da Anayasa Yargısı" adlı sunuşu bu türden.

Bir diğer grup olarak "tanıtıcı yönü ağır basan" çalışmaları ayrimlamak mümkün. NYGH'in "Avustralya, Kanada ve ABD Anayasa Yargisında Taraf Olma Ehliyeti" adl (Ingilizce) bildirisi, WIECHERS' in Güney Afrika Cumhuriyeti Anayasası ve Anayasa Yargısı üzerine yaptığı karşılaştırmalı çalışma. Polonya Yüksek Mahikemesi ile llgill olarak GARLICKI'nin sundư̆u bildiri, TİKVEŞ'in 'Karşılaştırmalı Hukuk Açısından Türkiye'de Anayasa Yargısı", TAKADA'nın "Alman 
Hukuk Devleti Teorilerinin Japonya'ya Etkisi", ABE'nin "Karşılaştırmalı Hukuk Açısından Japonya'da Anayasa Yargısı" MBAYA'nın "Afrika Hukuk Düzenlerinde Yeni Gelişmeler" adlı çalışmalarının tanıtıcı nitelikleri ağır basıyor.

Anayasa Hukuku ile ilgili bölümde doğal olarak Anayasa Yargusı ile ilgili konular ağırlık kazanıyor. Alman Anayasa Mahkemesi üyesi olan GEIGER, bu alanın temel sorusunu da tartışıyor: Anayasa Mahkemelerinin yetkileri. GEIGER üyesi olduğu mahkemeye yöneltilen "yetkilerini aşma" eleştirisini yanıtlarken, tüm Anayasa Mahkemeleri adina genel bir savunma yapiyor aslinda. Alman Federal Anayasa Mahkemesinin yetkilerini denetleyebilecek bir organ olmadığına göre, mahkeme yetkilerinin sinırlarını kendisi çizecektir sonucuna varan GEIGER "mahkeme yetkilerini aşmaktadır" iddialarının polemik yapma dışında bir anlamı olamayacağını belirtiyor.

Anayasa Yargisını ele alan bildirilerin, anayasa yargisina yaklaşımları genellikle olumlu olmakla birlikte, ARMAĞAN konuya daha kritik bir yaklaşım içinde görünüyor. Sorunu özellikle gelişmekte olan ülkeler açısından ele alan ARMAĞAN, Anayasa Yargısının bu ülkelerin muhtaç olduğu istikrar ve güçlü yürütmeyi engeller sonuçlar verdiğini savunuyor. Bu kanısını Türkiye'den örnekler vererek belgelemek isteyen ARMAĞAN, Anayasa Yargısını bir yanılgı olarak ("errara humanum est") niteliyor.

Toplantıya Türkiye'den katılan üçüncü anayasacı SAĞLAM'ın çalışması Türkiye deneyimlerinden kaynaklanmakla beraber, genel bir nitelik de taşıyor : "Anayasa Yargısının Siyasal Düzenin ve Kamu Hukukunun Gelişimine Etkisi". SAĞLAM bu etkiyi dört noktada ele almiş :

a) Yasa boşluklarının ortaya çıkması. (Bu nokta sanıyorum daha çok Türkiye'deki uygulamaya özgü bir durum).

b) Anayasa Mahkemesinin - karar gerekçeleri yoluyla- yasama üzerindeki etkisinin artması,

c) Yasamanın zayıflaması ve Anayasa Mahkemesinin yetki alanınun genişlemesi,

d) Küçük partilerin - siyasal azınlıkların-- yasama sürecinde etkilerinin artmasi.

Bu çalışmaların yanı sıra Kamu Hukukunun "ezeli" sorunlarını ele alan çalışmalar da var. KURUKI "Anayasa Yargısı ve Halk Egemenliği" adlı bildirisinde bu sorunu, Halk Egemenliği ilkesini "real" 
ve "ideal" olmak üzere iki unsura ayırarak aşmak çabasında. Halkın güncel iradesinin gerçeklik kazanmasını halk egemenliğinin "real" unru, halkın gerçek (?) çıkarlarının gerçekleştirilmesini ise "ideal" unsurun olarak ele alan KURUKI'nin vardığı sonuç, seçim yoluyla temsil yetkisl alanların (yasama organı ve hükümet) ve halk katılımının çeiştli biçimlerinin esas olarak halk egemnliğinin "real" yönünün bir ifadesi olduğu, mahkemeler ve özellikle Anayasa Mahkmesinin ise halk egemenliğinin "ideal” yönünü temsil ettiğidir. Bildiri sahibi, azınl1ğn korunmasına tanıdığı merkezi yer nedeniyle, genel çıkarın sağlanmasını mahkemelerin görevi saymaktadır.

HUH'un çalışması da - Türkiye için çok güncel olmayan-böyle bir genel sorunu inceliyor : Sosyal devletin sinırları.

Önce Alman Hukukunda çok yaygin olan ve Sosyal Devlet ile Hukuk Devletinin birbirlerini karşllıklı sinırladığı yolundaki görüşü eleştiren HUH, sosyal devletin özünde özgürlüğü sinırlayıcı, hukuk devletinin ise özgürlüğü koruyucu kabul edilmesinin yanlış sonuçlara götüreceğine işaret ediyor. Sosyal devleti demokrasinin ve özgürlüğün bir koşulu olarak ele alan çalışmacıya göre, gerek hukuk devletinin, gerekse sosyal devletin sunirlarını "sisteme uygunluk" belirleyecektir. Bu nedenle her iki ilkenin içerdiği özgürlüğü "optimum" düzeyde gerçekleştirmeyi engelleyecek "sistemi aşan" tüm uygulamalar demokrasinin işleyişini zedeleyecektir.

Bir diğer Japon hukukçusu -ISHIMURA- "Japonya'da Özellikle Düşünce ve Haberleşme özgürlüğü Açılarından Temel Haklar Alanındaki Yeni Gelişmeler" adlı bildirisine sorularla başlıyor :

a) Günümüz sanayi toplumlarında temel haklar -özellikle Düşünce ve Haberleşme Özgürlüğü - zedelenmekte midir?

b) $\mathrm{Bu}$ olguya ne gibi toplumsal ve hukuki yöntemlerle karşı konulabilir?

ISHIMURA Japonya ömeğinden hareketle bir genellemeye vararak, sanayi toplumlarında devletin ve büyük çıkar çevrelerinin toplumda etkilerinin arttığına, bunu dengeleyecek demokratik denetim kurumlarının ise yeterince oluşturulamadığına dikkati çekiyor. Ortaya çıkan bu dengesizlik, yazara göre, Düşünce Özgürlüğünü tehdit etmektedir.

Italyan kamu hukukçusu ROSSANA "Anayasa Hukuku Açısından Örfi Hukuk" adl bildirisinde, Anayasa Hukukunun aslinda Örfi $\mathrm{Hu}$ kuka yabancı olduğu sonucuna varıyor. Gerçekten, sempozyumun 'anayasa hukuku çalışma grubu' raportörü BADURA'nın da belirttiği 
gibi, modern anayasaların son derece ayrintılı hükümler içermeleri ve kendi değiştirilme yöntemlerini açıklıkla saptamaları, örfi hukuk düşüncesinin bir yana itilmesine yol açmıştrr.

Alman anayasa hukukçusu STEIGER'in çalışması klasik bir alanı özgün bir şekilde ele alıyor: "Yaşam Hakku ve Kişi Dokunulmazlığa".

STEIGER sorunu Alman Federal Anayasa Mahkemesinin konuya ilişkin -yeni- kararları çerçevesinde inceliyor. Ama bu inceleme "yaşam hakkı ve kişi dokunulmazlığı"nın çağımızda kazandığı yeni anlamın ana çizgilerini ortaya koymağa da yetiyor. Yazar bu hakların devlete karşi koruyucu nitelikleri üzerinde pek durmadan, bizzat devlete koruyucu/olumlu görevler yükleyen ve çevre korunmasından, bir rehinenin (Hans Martin Schleyer) hayatına karşı bazı suçluların b1rakılmasının gerekip, gerekmediği noktasına kadar yayılan bir alanda bu yeni anlamı tartışiliyor.

Bildiri sahibi, yaşam hakkının işlevinin diğer klasik özgürlüklerden farklı olduğunu vurgularken, anayasanın bütünlüğü içinde bu hakkın sosyal devlet ilkesi ile olan ilişkisine de haklı olarak dikkati çekiyor. (Steiger'in çalışmasını okurken, 1961 anayasasının 10. maddesinin akla gelmemesi olanaksiz).

Son olarak, kitabın Devletler Hukuku ile ilgili bildirileri kapsayan bölümündeki çalışmaların çoğunun anayasa hukukçuları açısından önem taşıdığını belirtmek gerekiyor. OPPERMAN Federal Almanya, PANEBIANCO ise İtalyan anayasası açlarından Avrupa birliği sorununu ele alıyorlar. TOMUSCHAT ve KOBAYASHI insan haklarmm uluslararası korunmasinı inceliyorlar.

Yapıt tüm kamu hukukçularına yararh olacak niteliktedir. 